\title{
Is It True That Transformational Leadership Style Can Shape Employees Motivation and Performance?
}

\author{
Hafid Kholidi Hadi *)
}

\begin{abstract}
Today the world is experiencing very rapid progress in all aspects of life. Along with these advances, strong human resources with good the quality are increasingly needed to face the rapid and continuous change. Limited Liability Company (Perseroan Terbatas/PT) is a profit-oriented business entity. PT. Berau Karya Indah is a new PT in raw material processing industry which is trying to develop production in the manufacturing sector. This study can be categorized into a causality study because this study aims to discuss and analyze the influence of transformational leadership style on employees performance and motivation in PT. Berau Karya Indah Surabaya. The data analysis in this study used Structural Equation Modeling (SEM). The population used in this study is all 340 employees of the company. Sample size in this study included 172 respondents who were selected using random sampling technique. The result of this research indicates that transformational leadership style has a significant influence on employee performance and transformational leadership has a significant impact on employees work motivation.
\end{abstract}

Keywords: Transformational Leadership; Performance; Motivation

\section{INTRODUCTION}

\subsection{Research Background}

Within a company no matter how sophisticated the technology of machinery and equipment that it has and uses, human resources remain an important factor in the success of an organization, both large-scale, and small-scale organizations. Every company has a structure that indicates indicating a line of responsibility used to create maximum performance. In this modern era, where the flow of information and science and technology progress have developed so rapidly, a company has to face the reality that some aspects of the organization require changes and developments. And since these changes and developments are inevitable, the company's leader has an important role in responding to both. A leader must thoroughly understand the employee's behavior and have the capability to encourage the employees to perform the tasks according to their responsibility. Soane, Butler, \& Stanton (2015) suggest that the transformational leadership style has a positive impact on employee performance. This statement is similar to Ugwu, Enwereuzor, \& Orji (2016), that transformational leadership provides positive predictions in role performance. Transformational leadership has a significant influence on work motivation, and work motivation has a positive effect on employees performance (Syaifuddin, 2016). Studies by Pongpearchan (2016) show that transformational leadership and high-performance work system have a positive and significant influence on work motivation.

\subsection{Research Problem}

a) Does a transformational leadership style that includes charisma, inspiration, intellectual stimulation, and simultaneous individualized attention have a significant effect on employee performance and motivation in PT. Berau Karya Indah?

b) Which are the dominant influence on employees performance and motivation in PT. Berau Karya Indah? 


\subsection{Research Purpose}

The objectives of this research are to analyze the significant influence of transformational leadership variables -that includes charisma, inspiration, intellectual stimulation, and simultaneous individualized attention- on employee performance and motivation, and to analyze the dominant influence of the transformational leadership variables on employees performance and motivation in PT. Berau Karya Indah.

\section{THEORETICAL FRAMEWORK AND HYPHOTESES DEVELOPMENT}

\subsection{Transformational Leadership}

Yukl (2005) state that leadership is the ability of an individual to influence, to motivate, and make others able to contribute to the effectiveness and success of the organization. Another suggestion that an organization requires a leader is expressed by Gibson (1993). He said that the most influential people in the group might be called leaders. Leaders are important in a variety of organizational environments. Actually, organizations will become less efficient without leaders. Leadership style changes over time because a leader must be able to anticipate the future life of the organization or company. In this Yukl (2005) states, transformational leadership and transactional leadership are different, but not an equally exclusive process. Transformational leadership further enhances the follower's motivation and performance compared to transactional leadership. As stated by Burns (1978), transformational leadership calls on the moral values of followers in their efforts to raise their awareness of ethical issues and to mobilize their energies and resources to reform institutions.

Basically, leadership behaviors can be categorized based on their orientation: task-oriented leadership behaviors and relationship-oriented leadership behaviors. Transactional leadership style, which focuses more on the relationship of leader and subordinates without any effort to create changes for the subordinates, is task-oriented leadership behavior. While the transformational leadership style, in which a leader focuses on achieving changes in the values of beliefs, attitudes, behaviors, emotions and the subordinates needs of better change in the future, is relationshiporiented leadership behavior (Yukl, 2005). The difference is that transactional leaders use rewards as a control mechanism for exchanging relationships that are explicitly established to externally motivate followers, while transformational leaders use rewards as a component of a system designed to increase followers commitment and to motivate followers (Liu, 2007). According to Ranupandojo \& Husnan (1995) style of leadership is as a pattern of behavior designed to integrate organizational goals with the individual goal to achieve a certain goal. It is in this leadership style that a person is chosen as a leader or manager because it is closely related to the objectives of the company to be achieved, the types of activities to be led, the characteristics of the labor, the business motives, and others. The ideal style of leadership uses all the available styles to the best of it. This means that situations may determine the style model that can be used. An effective leader should pay attention to the people, employees, production and strive to create a climate of job satisfaction and achievement of work that can produce the best quality.

\subsection{Motivation}

Work motivation plays a very important role in determining the success of employees in carrying out the tasks assigned to them. As stated by Anoraga (2006), the motivation of work is something that raises the spirit or the drive to work. Robbins (1998) argues that human beings are always in a state of continuity. If a need is met, it is immediately replaced by other needs. Maslow expressed the hierarchy of employees needs as follows: 
- $\quad$ Physiological needs, an example of the need for food, drinks, physical protection, breathing, and sex. About this need, a leader has to provide decent salaries to employees.

- $\quad$ The need for a sense of security, an example of the need for protection from threats and the dangers of the work environment. About this need, a leader has to provide health benefits, accident insurance, housing, and pension funds.

- $\quad$ Social needs, an example of the need to be accepted in the workgroup, to interact, to love and be loved. About this need, a leader has to accept the existence of employees as members of the working group and create a good interaction work and a harmonious working relationship.

- $\quad$ The need for self-esteem, an example of the need to be respected and appreciated by others. Concerning this need, a leader should not arbitrarily treat employees because they need to be respected and rewarded for their work performance.

- Needs of self-actualization, an example of the need to develop self-potential, put forward ideas, and provide judgment, criticism, and achievement. To these need, a leader has to provide opportunities for the employees so that they can actualize themselves well and reasonably in the company.

\subsection{Performance}

According to Siagian (1995), performance is the behavior that is exposed by individuals or groups. Regarding behavior, a person personality often manifests itself in the form of attitudes, ways of thinking, and how to act and the things that affect the personality of an organizational person reflected in the behavior that will affect the performance.

\subsection{The Influence of Transformational Leadership on Motivation and Performance}

According to Yukl (2005), transformational leadership further enhances the follower's motivation and performance. The same is expressed by Mujiasih \& Hadi (2003), that the practice of a transformational leadership style is capable of bringing about changes that have an impact on subordinates motivation, or changes that enable subordinates to increase their motivation to make extra efforts in achieving a performance beyond expected. A study conducted by Vigoda \& Gadot (2006) also concludes that transformational leadership has a positive relationship with performance. This is in line with a study conducted by Zareen, Razzaq, \& Mujtaba (2015) that states the transformational leadership style has a positive impact on subordinates motivation. Similarly, leadership styles control interpersonal, reward and punishments that shape employee behavior, motivation, and attitudes, which impact organizational performance (Puni, Ofei, \& Okoe, 2014). Leaders who practice the quality of idealized influences, intellectual stimulation, inspirational motivation, and individual considerations, become successful in engaging their subordinates in making extra efforts (Balyer, 2012). Therefore, the hypotheses of this study are:

$\mathrm{H}_{1}$ : Transformational leadership affects employees performance.

$\mathrm{H}_{2}$ : Transformational leadership affects employees work motivation.

\section{RESEARCH METHOD}

\subsection{Research Design}

This study can be categorized into a causality study because its purpose is to obtain evidence of the causal relationship of research variables (Maholtra, 2005), which is to determine the effect of transformational leadership style on employees performance and motivation. The data analysis in this study used Structural Equation Modeling (SEM) which was operated through the program Analysis of Moment Structure (AMOS) 16.0. SEM analysis is aimed to obtain a structural model. The model obtained can be used to predict or prove the models. Besides, SEM can also be used to 
see the magnitude of the influence, either directly or indirectly, or the effect of the total independent variable (exogenous variable) on the dependent variable (Endogen) (Sugiyono, 2009). Analysis of Moment Structure (AMOS) is one of the programs used to process multidimensional and tiered research models. As a model of structural equations, AMOS has often been used in strategic management research Ferdinand (2005) found that the appropriate sample size was between 100200 participants.

The independent variable in this study is the transformational leadership style. Transformational leadership calls for the moral values of followers in their efforts to raise their awareness of ethical issues and to mobilize their energy and resources to reform institutions. There are four components of the behavior of transformational leaders: charisma, inspiration, intellectual stimulation, and individualized attention. The dependent variables in this study are performance and work motivation. Gomes (2003) stated that, performance is the result of work done by a person or group within a certain time. Performance variables are measured using the following indicators:

a) Quantity of Work defined as the amount of work contained within a certain period of time.

b) Quality of Work defined as the quality of work achieved under the terms of conformity and readiness.

c) Job Knowledge defined as knowledge of work and skills

d) Creativeness defined as the originality of emerging ideas and actions to solve the existing problems

e) Cooperative defined as willingness to cooperate with others (fellow members of the organization)

f) Dependability, in example awareness and credibility in terms of attendance and work completion.

g) Initiative, in example the spirit to perform new tasks and in enlarging responsibilities.

h) Personal qualities, ie personality, leadership, hospitality and personal integrity.

Meanwhile, the assessment of work motivation in this study is based on Maslows opinion that says that employees motivation is determined by the following five factors:

a) Physiological needs (salary, worship time, workplace comfort)

b) Needs of security (the existence of jamsostek (Social and Employment Security), pensions, job risk protection, corporate stability)

c) Social needs (employees feel like they are part of a family, the company organizes activities that involve all employees, employees help out each other)

d) Needs of self-esteem (awards for education, awards for work experience, awards for nonacademic ability, gender equality in employment, equality of workloads)

e) Needs of self-actualization (employees creativity, achievement awards and career development are provided, employees are involved in solving problems, giving confidence to employees in completing the work).

\subsection{Population and Sample}

The population used in this study was the employees of PT. Berau Karya Indah Surabaya that consisted of 340 people (264 males and 76 females). The sample was also PT. Berau Karya Indah Surabaya employees, who were 172 people in total. This sample was taken using a simple random sampling technique. The sample members were selected randomly from the population regardless of the strata within the population. The total number will be randomly divided, consisting of employees of Production, HRD \& GA (general affair), Finance \& ACC (accounting), and Export divisions. 


\subsection{Research Framework}

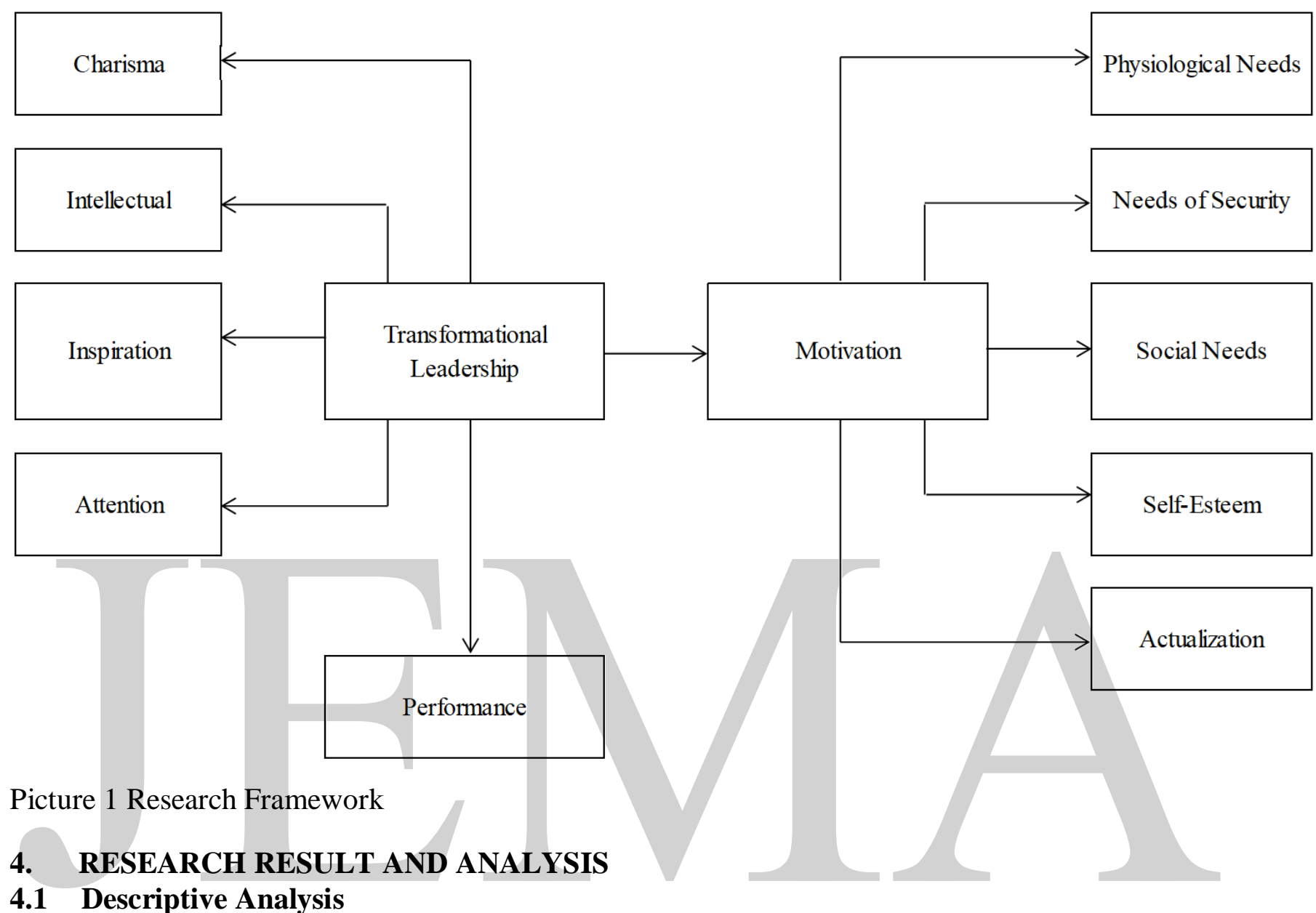

Table 1 Distribution of Respondent (Sex)

\begin{tabular}{|l|l|l|l|}
\hline Variable & Category & Frequency & Percentages \\
\hline \multirow{2}{*}{ Sex } & Male & 140 & $81,4 \%$ \\
\cline { 2 - 4 } & Female & 32 & $18,6 \%$ \\
\hline
\end{tabular}

Source: Primary Data Processed, 2018

Table 2 Distribution of Respondent (Education Level)

\begin{tabular}{|l|l|l|l|}
\hline Variable & Category & Frequency & Percentages \\
\hline \multirow{3}{*}{ Education Level } & Senior High School (SMA/SLTA) & 143 & $83,1 \%$ \\
\cline { 2 - 4 } & Diploma & 23 & $13,4 \%$ \\
\cline { 2 - 4 } & S1 (Bachelors Degree) & 6 & $3,5 \%$ \\
\hline
\end{tabular}

Source: Primary Data Processed, 2018

JEMA: Jurnal Ilmiah Bidang Akuntansi dan Manajemen is licensed under a

Creative Commons Attribution 4.0 International License 
JEMA: Jurnal Ilmiah Bidang Akuntansi dan Manajemen, Vol. 15 No. 2 (2018)

http://riset.unisma.ac.id/index.php/jema (e-ISSN : 2597-4071)

Table 3 Distribution of Respondent (Work Duration)

\begin{tabular}{|l|l|l|l|}
\hline Variable & Category & Frequency & Percentages \\
\hline \multirow{3}{*}{ Work Duration } & $<1$ Year & 35 & $20,3 \%$ \\
\cline { 2 - 4 } & $1-2$ Year & 122 & $70,9 \%$ \\
\cline { 2 - 4 } & $2-3$ Year & 15 & $8,7 \%$ \\
\hline
\end{tabular}

Source: Primary Data Processed, 2018

Based on the table of respondent characteristics, it can be concluded that:

- $\quad 81.4 \%$ of the employees at PT. Berau Karya Indah are male (140 people) and $18.6 \%$ are female (32 people).

- $\quad$ The majority of employees at PT. Berau Karya Indah are high school graduates (143 people / 83.1\%), followed by Diploma graduates (23 people / 13.4\%), and S1 / Bachelors Degree graduates $(6 / 3.5 \%)$.

- $\quad$ The majority of employees in PT. Berau Karya Indah has worked for the company for 1-2 years, where as many as 122 people (70.9\%) have worked for 1-2 years, 35 people $(20.3 \%)$ have worked for less than 1 year, and 15 people $(8.7 \%)$ have worked for $2-3$ years.

\subsection{Validity and Reliability}

Validity test was done through convergent validity, where an indicator is said to have convergent validity if it has standardized regression weight value of $>0.50$ and has a GFI value of 1 or close to it. While a dimension or variable is said to be reliable if it has a reliability construct value of 0.7 .

Table 4 Convergent Validity and Reliability Construct Test

\begin{tabular}{|c|c|c|c|c|c|}
\hline \multirow{2}{*}{ Indicator } & \multicolumn{3}{|c|}{ Validity Test } & \multirow{2}{*}{$\begin{array}{l}\text { Construct } \\
\text { Reliability }\end{array}$} & \multirow{2}{*}{ Status } \\
\hline & Estimate & $\mathrm{P}$ & Status & & \\
\hline $\mathrm{X} 1$ & 0,988 & Fix & Valid & \multirow{5}{*}{0.716} & \multirow{5}{*}{ Reliable } \\
\hline $\mathrm{X} 2$ & 0,992 & Fix & Valid & & \\
\hline $\mathrm{X} 3$ & 0,993 & Fix & Valid & & \\
\hline $\mathrm{X} 4$ & 0,986 & Fix & Valid & & \\
\hline $\mathrm{X5}$ & 0,997 & Fix & Valid & & \\
\hline $\mathrm{X} 6$ & 0,994 & Fix & Valid & \multirow{3}{*}{0,728} & \multirow{3}{*}{ Reliable } \\
\hline $\mathrm{X} 7$ & 0,994 & Fix & Valid & & \\
\hline $\mathrm{X} 8$ & 0,997 & Fix & Valid & & \\
\hline $\mathrm{X9}$ & 0,992 & Fix & Valid & \multirow{3}{*}{0,686} & \multirow{3}{*}{ Reliable } \\
\hline $\mathrm{X} 10$ & 0,995 & Fix & Valid & & \\
\hline $\mathrm{X} 11$ & 0,997 & Fix & Valid & & \\
\hline $\mathrm{X} 12$ & 0,987 & Fix & Valid & \multirow{3}{*}{0,731} & \multirow{3}{*}{ Reliable } \\
\hline $\mathrm{X} 13$ & 0,995 & Fix & Valid & & \\
\hline X14 & 0,998 & Fix & Valid & & \\
\hline
\end{tabular}

Source: Primary Data Processed, 2018 
JEMA: Jurnal Ilmiah Bidang Akuntansi dan Manajemen, Vol. 15 No. 2 (2018)

http://riset.unisma.ac.id/index.php/jema (e-ISSN : 2597-4071)

Table 5 Convergent Validity and Reliability Construct of Employee Performance Test

\begin{tabular}{|c|c|c|c|c|c|}
\hline \multirow{2}{*}{ Indicator } & \multicolumn{3}{|c|}{ Validity Test } & \multirow{2}{*}{$\begin{array}{l}\text { Construct } \\
\text { Reliability }\end{array}$} & \multirow{2}{*}{ Status } \\
\hline & Estimate & $\mathrm{p}$ & Reliability & & \\
\hline y1.1 & 0,995 & Fix & Valid & \multirow{8}{*}{0,717} & \multirow{8}{*}{ Reliable } \\
\hline $\mathrm{y} 1.2$ & 0,992 & Fix & Valid & & \\
\hline y1.3 & 0,987 & Fix & Valid & & \\
\hline $\mathrm{y} 1.4$ & 0,990 & Fix & Valid & & \\
\hline$y 1.5$ & 0,988 & Fix & Valid & & \\
\hline y1.6 & 0,981 & Fix & Valid & & \\
\hline y1.7 & 0,995 & Fix & Valid & & \\
\hline$y 1.8$ & 0,995 & Fix & Valid & & \\
\hline
\end{tabular}

Source: Primary Data Processed, 2018

Table 6 Convergent Validity and Reliability Construct of Employee Motivation Test

\begin{tabular}{|c|c|c|c|c|c|}
\hline \multirow{2}{*}{ Indicator } & \multicolumn{3}{|c|}{ Validity Test } & Construct & \multirow{2}{*}{ Status } \\
\hline & Estimate & P & Status & Reliability & \\
\hline Y2.1 & 0,996 & Fix & Valid & & \\
\hline Y2.2 & 0,993 & Fix & Valid & & \\
\hline Y2.3 & 0,990 & Fix & Valid & & \\
\hline Y2.4 & 0,995 & Fix & Valid & & \\
\hline Y2.5 & 0,994 & Fix & Valid & & \\
\hline Y2.6 & 0,993 & Fix & Valid & & \\
\hline Y2.7 & 0,977 & Fix & Valid & & \\
\hline Y2.8 & 0,995 & Fix & Valid & \multirow{3}{*}{0,717} & \\
\hline Y2.9 & 0,995 & Fix & Valid & & \\
\hline Y2.10 & 0,994 & Fix & Valid & & \\
\hline Y2.11 & 0,994 & Fix & Valid & & \\
\hline Y2.12 & 0,992 & Fix & Valid & & \\
\hline Y2.13 & 0,981 & Fix & Valid & & \\
\hline Y2.14 & 0,993 & Fix & Valid & & \\
\hline Y2.15 & 0,996 & Fix & Valid & & \\
\hline Y2.16 & 0,981 & Fix & Valid & & \\
\hline Y2.17 & 0,998 & Fix & Valid & & \\
\hline
\end{tabular}

Source: Primary Data Processed, 2018

Based on the table, it is known that:

a) All items of questions on the dimensions of charisma, inspiration, intellectual, and attention have the value of standardized regression weight greater than 0.5 , and the value of construct reliability greater than 0.5 . Thus the question items that shape the dimensions of the inspirational, intellectual, and attention charisma are valid and reliable.

b) All question items on the performance dimension have standardized regression weight value greater than 0.5 , and construct reliability value of 0.717 . Thus the question items that make up the performance dimension are valid and reliable. 
c) All items of questions on the physiological, security, social, reward, and self-actualization dimensions have standardized regression weight greater than 0.5 , and construct reliability value greater than 0.5 . Thus the question items that form the physiological, security, social, reward, and self-actualization dimensions are valid and reliable.

\subsection{Research Analysis}

Table $7 \mathrm{GoF}$

\begin{tabular}{|l|c|c|c|}
\hline \multicolumn{1}{|c|}{ Godness of Fit Index } & Cut Off Value & Result & Decision \\
\hline Probability & $\geq 0,05$ & 0,089 & Good \\
\hline Chi-Square/DF. & $\leq 2,00$ & 2,120 & Marginal \\
\hline GFI & $\geq 0,90$ & 0,956 & Good \\
\hline TLI & $\geq 0,95$ & 0,936 & Marginal \\
\hline CFI & $\geq 0,95$ & 0,967 & Good \\
\hline RMSEA & $\leq 0,08$ & 0,065 & Good \\
\hline AGFI & $\geq 0,90$ & 0.921 & Good \\
\hline
\end{tabular}

Source: Primary Data Processed, 2018

Based on the results of the fit model, it is known that there is 2 models in marginal and good enough category, and 5 models are in a good category. Therefore, the conclusion of this research model is good and data analysis can be continued to the hypothesis discussion stage.

\subsection{Research Discussion}

Table 8 Regression Weight and Standardized Regression Structural Model

\begin{tabular}{|l|c|l|c|c|c|c|c|}
\hline \multicolumn{2}{|l}{} & Est & SE & CR & P & Conclusion \\
\hline Performance & $<---$ & Transform_Lead & .997 & .001 & 179.046 & .000 & Accepted \\
\hline Motivation & $<---$ & Transform_Lead & .999 & .002 & 259.321 & .000 & Accepted \\
\hline
\end{tabular}

$* * *) \mathrm{P}=>0.05$ and $\mathrm{CR}>1.96$

Source: Primary Data Processed, 2018

This study is related to the discussion and findings of studies that have been done by other researchers before, including research by Gyanchandani (2017), which states that transformational leadership impacts positively on team performance. The results reveal that transformational leaders make employees work in a more creative way that in turn makes the environment creative as well. Jiang, Zhao, \& Ni (2017) also found that employees sustainable performance is influenced by transformational leadership. The study was conducted in the construction industry. Caillier (2014) revealed that transformational leadership and Public Service Motivation (PSM) have a direct and positive effect on employee evaluations. He also revealed that the mission reinforces a positive relationship between transformational leadership and performance. However, PSM does not have the same effect on the relationship between leadership and transformational performance. This research is different if done on objects like the manufacturing industry, where divisions are interrelated so that the business process can run on schedule. From the four dimensions of transformational leadership variables, the charisma dimension has a higher value compared to other dimensions. This indicates that company leaders charisma make employees feel comfortable when working around them. Leaders in PT. Berau Karya Indah has an obligation company culture to lead 
by example. Leaders also give mentoring to increases employees motivation. This finding supports the research conducted by Pongpearchan (2016) which shows that transformational leadership and high-performance work systems have a significant positive impact on work motivation. And Caillier (2014) reveals that transformational leadership and PSM have a direct, positive effect on employee evaluations. Ahmad, Abbas, Latif, \& Rasheed (2014) concluded that there is a significant relationship between transformational leadership and employees motivation.

\section{RESEARCH CONCLUSION AND LIMITATION}

\subsection{Conclusion}

Transformational leadership style has proven to improve employees performance in PT. Berau Karya Indah Surabaya. This is because the four dimensions that form the transformational leadership variables are applied through coordination in the completion of work. Charisma is the dominant transformational leadership dimension in this research. Leaders in PT. Berau Karya Indah has an obligation company culture to lead by example. Personalized charisma, intellectual, inspirations, and attention (mentoring) also proved in increasing employees motivation at this research.

\subsection{Limitation}

This study has its limitations, it only looked at the leadership style in one company. The next researcher is expected to conduct research that studies the characteristics of different leadership styles in several categories of companies to provide better generalization. That way, the best leadership style can be revealed to improve employees performance and motivation.

\section{REFERENCES}

Ahmad, F., Abbas, T., Latif, S., \& Rasheed, A. (2014). Impact of Transformational Leadership on Employee Motivation in Telecommunication Sector. Journal of Management Policies and Practices, 2(2), 11-25. http://doi.org/10.15640/jmpp.

Anoraga, P. (2006). Psikologi Kerja. Cetakan keempat. Jakarta: Rineka Cipta

Balyer, A. (2012). Transformational Leadership Behaviors Of School Principals: A Qualitative Research Based On Teachers Perceptions. International Online Journal of Educational Sciences, 4(3), 581-591.

Caillier, J. G. (2014). Toward a Better Understanding of the Relationship Between Transformational Leadership, Public Service Motivation, Mission Valence, and Employee Performance: A Preliminary Study. Public Personnel Management, 43, 218. http://doi.org/10.1177/0091026014528478.

Ferdinand, A. (2005). Structural Equation Modelling (SEM). Edisi ketiga. Semarang: Badan Penerbit Undip.

Gibson, J. L. (1993). Organisasi. Edisi Kelima, Jakarta: Erlangga.

Gomes, F. C. (2003). Manajemen Sumber Daya Manusia. Edisi Pertama. Yogyakarta: Andi Offset.

Gyanchandani, R. (2017). The Effect of Transformational Leadership Style on Team Performance in IT Sector. IUP Journal of Soft Skills, 11(3), 29-44. 
Jiang, W., Zhao, X., \& Ni, J. (2017). The Impact of Transformational Leadership on Employee Sustainable Performance: The Mediating Role of Organizational Citizenship Behavior. Sustainability 2017, 9, 1567. http://doi.org/10.3390/su9091567

Liu, C. H. (2007). Transactional, Transformational, Transcendental Leadership:Motivation Effectiveness And Measurement Of Transcendental Leadership. Retrieved from http://goo.gl/QawtnZ

Maholtra, N. K. (2005). Riset Pemasaran: Pendekatan Terapan. Terjemahan. Edisi keempat. Jilid 1. Jakarta: Indeks.

Mujiasih, E., \& Hadi, S. (2003). Persepsi Gaya Kepemimpinan Transformasional Dan Transaksional. Jurnal Bisnis dan Ekonomi, September.

Pongpearchan, P. (2016). Effect of Transformational Leadership and High Performance Work System on Job Motivation and Task Performance: Empirical Evidence from Business. The Journal of Business and Retail Management, 10(3), 93-106. Retrieved from http://www.jbrmr.com/admin/content/pdf/i-24_c-232.pdf.

Puni, A., Ofei, S. B., \& Okoe, A. (2014). The Effect Of Leadership Styles On Firm Performance In Ghana, International Journal of Marketing Studies, 6(1), 177. http://dx.doi.org/10.5539/ijms.v6n1p177.

Ranupandojo, H., \& Husnan, S. (1995). Manajemen Personalia. Edisi Keempat. Yogyakarta: Andi Offset.

Robbins, S. P. (1998). Perilaku Organisasi. Edisi kedelapan. Terjemahan. Jakarta: Prehallindo.

Siagian, S. P. (1995). Teori Pengembangan Organisasi. Cetakan ketiga. Jakarta: Bumi Aksara.

Soane, E., Butler, C., \& Stanton, E. (2015). Followers Personality, Transformational Leadership And Performance. Sport, Business and Management: An International Journal, 5(1), 65-78. https://doi.org/10.1108/SBM-09-2011-0074.

Sugiyono. (2009). Statistika Untuk Penelitian. Bandung: Alfabeta.

Syaifuddin. (2016). The Influence of Work Stress and Transformational Leadership on Work Motivation and Implication of EmployeeS Performance (Case Study). Academy of Strategic Management Journal, 15(3), 42-49. Retrieved from https://search.proquest.com/docview/1954386500/fulltextPDF/FAFC9687F6124799PQ/1?acc ountid $=15920$.

Ugwu, L. I., Enwereuzor, I. K., \& Orji, E. U. (2016). Is Trust In Leadership A Mediator Between Transformational Leadership And In-Role Performance Among Small-Scale Factory Workers? Review of Managerial Science, 10(4), 629-648. https://doi.org/10.1007/s11846015-0170-z.

Vigoda, E., \& Gadot. (2006). Leadership Style, Organizational Politics, And Employees Performance. Personnel Review, 36(5), 661-683. https://doi.org/10.1108/0048348071077398.

Yukl, G. A. (2005). Kepemimpinan Dalam Organisasi : Edisi Kelima. Jakarta. Indeks.

Zareen, M., Razzaq, K., \& Mujtaba, B. G. (2015). Impact of Transactional, Transformational and Laissez-Faire Leadership Styles on Motivation: A Quantitative Study of Banking Employees 
JEMA: Jurnal Ilmiah Bidang Akuntansi dan Manajemen, Vol. 15 No. 2 (2018)

http://riset.unisma.ac.id/index.php/jema (e-ISSN : 2597-4071)

in Pakistan. Public Organization Review, 15(4), 531-549. https://doi.org/10.1007/s11115014-0287-6.

*) Hafid Kholidi Hadi, Department of Management, State University of Surabaya, Surabaya Indonesia (Email : hafidhadi@ unesa.ac.id)

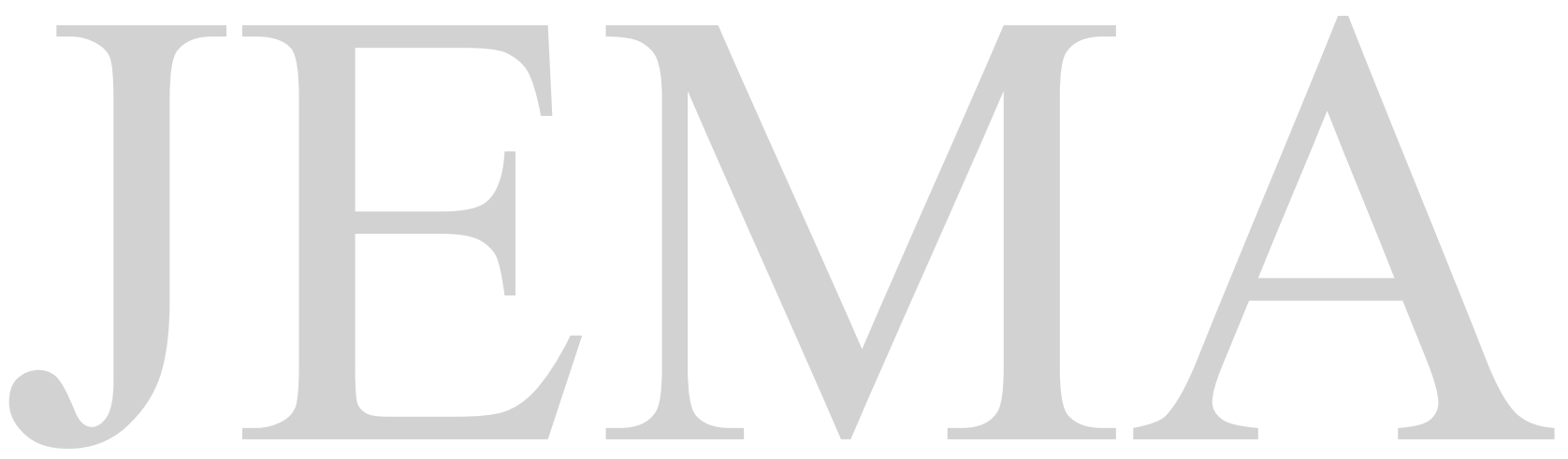

JEMA: Jurnal Ilmiah Bidang Akuntansi dan Manajemen is licensed under a Creative Commons Attribution 4.0 International License 